\title{
What's Law Got to do with it? Is Consumer Law the Solution to Problems Faced
}

\section{by Student Tenants?}

\section{Property Law, Private Rented Sector, Purpose Built Student Accommodation}

Emily Walsh, Portsmouth Law School, University of Portsmouth

This paper examines the extent to which law and regulation protects students renting from private individuals or private companies, as opposed to universities, in both of the main types of student accommodation, the private rented sector (PRS) and purpose built student accommodation (PBSA). It first examines the different problems faced by students in both tenure types, notably issues of repair and the failure of PBSA providers to complete accommodation in time for the beginning of term. Secondly, it considers consumerisation of private renting and the extent to which a consumer protection law approach can assist tenants generally, and students specifically. Thirdly, the paper explains how power relationships between students and landlords and issues with access to legal advice restrict access to justice for student as tenants. It is argued that whilst consumer contract law and consumer protection law have something to offer student tenants (particularly in the PBSA) a generic consumer approach to the rights of tenants is insufficient because the nature of the landlord and tenant relationship inhibits access to legal redress. It is concluded that in addition to improved consumer protections, a proactive approach by both local authorities and universities could significantly improve the experiences of students.

\section{INTRODUCTION}

The housing pathway of students in the UK has traditionally comprised two stages, involving occupation of university halls of residence for the first year of study and then sharing privately rented houses with friends in the second and third year. ${ }^{1}$ Under this model, problems faced by students have

\footnotetext{
${ }^{1}$ D P Smith and L Holt 'Studentification and 'apprentice' gentrifiers within Britain's provincial towns and cities: extending the meaning of gentrification' (2007) Environment and Planning A 142, 152; P Hubbard 'Geographies of studentification and purpose-built student accommodation: leading separate lives?' (2009) 41(8)
} 
largely related the quality and state of repair of accommodation in both stages and, in the second stage, overzealous landlords impinging quiet enjoyment with too frequent or inadequately notified visits. However, this model has changed with the growth of the Higher Education sector since the 1990s leading to commodification of all aspects of Higher Education, including accommodation. ${ }^{2}$ This commodification has paved the way for private providers of purpose built student accommodation (PBSA) to enter and thrive in the market. PBSA does not generally suffer from the problems of condition and repair faced by the private rented sector (PRS) which are largely issues such as mould and vermin. However, there have been concerns about flammable cladding since the fire at Grenfell Tower, and a recent fire in Bolton has shown that student accommodation is also at risk. ${ }^{3}$ Furthermore, where buildings in the PBSA have not been fully completed prior to occupation, 'snagging' issues may still be a problem. In addition to these concerns of safety and condition, a number of high-profile cases of late completion of PBSA blocks have caused controversy. ${ }^{4}$ This paper examines both the PRS and the PBSA sector and considers the extent to which the current law and regulation provide adequate protection for students, and whether a more consumer-oriented approach to private tenancies, as advocated by the Government and the Law Commission, would alleviate some of the problems.

Rapid growth in the Higher Education sector has led to significant changes in how student cities are occupied. According to the Office for National Statistics, the number of young people (aged 18 to 24)

\footnotetext{
Environment and Planning A 1903; M Holton and M Riley 'Student geographies: exploring the diverse geographies of students and Higher Education' (2013) 7(1) Geography Compass 61.

2 P Chatterton 'The student city: an ongoing story of neoliberalism, gentrification, and commodification' (2010) 42 Environment and Planning A 509; C Kinton 'De-studenitification: emptying housing and neighbourhoods of student populations (2016) 48(8) Environment and Planning A 1617; C Mulhearn and M Franco 'If you build it will they come? The boom in purpose-built student accommodation in central Liverpool: Destudentification, studentification and the future of the city' (2018) 33(5) Local Economy 477.

${ }^{3} \mathrm{E} V$ Jory 'To avoid blazes like Bolton's, we must radically overhaul student housing' (The Guardian, 21 November 2019), available at https://www.theguardian.com/education/2019/nov/21/to-avoid-blazes-likeboltons-we-must-radically-overhaul-student-housing.

${ }^{4}$ B Ellery, R Bennett and $\mathrm{N}$ Woolcok 'Universities under fire as accommodation crisis hits students' (The Times, 7 October 2019) available at https://www.thetimes.co.uk/article/universities-under-fire-as-accommodationcrisis-hits-students-3vp2wn8zp; A Ross 'Bristol University students live in Wales - because there's no space in Bristol halls' (Bristol Post, 11 September 2019) available at https://www.bristolpost.co.uk/news/bristolnews/bristol-university-students-live-wales-3306343.
} 
in full-time education almost doubled between 1992 and $2016 .{ }^{5}$ Although around 20 per cent of students live at home while studying at university ${ }^{6}$, most students live away from home during term time. As stated above, the housing pathway of students has traditionally comprised two stages. Firstly, students have spent the first year of study in university halls of residence and secondly, students have moved into shared private rented housing. ${ }^{7}$ This two stage process enables first year students to learn the rules of studenthood ${ }^{8}$ and acquire a sense of ontological security ${ }^{9}$. While the move into shared housing during the second and third years of study, facilitates more selective social interaction ${ }^{10}$ and the transition towards adulthood. ${ }^{11}$ Students often move houses again between the second and third year in order to get a better deal and to reconstitute the composition of their household. ${ }^{12}$

The first stage of the student housing pathway has fuelled a rapid development of blocks of PBSA since the 2000s. ${ }^{13}$ For students, the rise of new purpose built accommodation has been more than merely growth in response to demand, it presents a lifestyle choice and has been marketed as such. Purpose built student housing is now advertised as including gyms, cutting-edge technology, security and a range of other facilities frequently seen in apartment buildings designed to accommodate city professionals. ${ }^{14}$ Hubbard argues that students have been identified as a group which possesses a 'metropolitan habitus' and a willingness to pay a premium for inner city living. ${ }^{15}$ This choice is funded

\footnotetext{
${ }^{5}$ Office for National Statistics How has the Student Population Changed (2016) see website available at https://www.ons.gov.uk/peoplepopulationandcommunity/birthsdeathsandmarriages/livebirths/articles/howh asthestudentpopulationchanged/2016-09-20.

${ }^{6}$ Higher Education Statistics Agency 'Chart 4 - Full-time and Sandwich Students by Term-Time Accommodation 2014/15 to 2017/18' webpage available at https://www.hesa.ac.uk/data-and-analysis/students/chart-4.

7 D P Smith and P Hubbard 'The Segregation of Educated Youth and Dynamic Geographies of Studentification' (2014) Area 92, p 93.

${ }^{8}$ P Chatterton 'University Students and City Centres - The Formation of Exclusive Geographies' (1999) 30 Geoforum 117.

${ }^{9}$ D P Smith and L Holt 'Studentification and 'apprentice' gentrifiers within Britain's provincial towns and cities: extending the meaning of gentrification' (2007) 39(1) Environment and Planning A 142, 152.

${ }^{10}$ Ibid, p 152.

${ }^{11} \mathrm{C}$ Holdworth 'Going away to uni? Mobility, modernity and independence of English education students' (2009) 15 Population and Space 225.

${ }^{12}$ H Christie, M Munro and R Rettig 'Accommodating students' (2002) 5(2) Journal of Youth Studies 210.

${ }^{13}$ Above $n 7$, p 95.

${ }^{14} \mathrm{lbid}$.

${ }^{15} \mathrm{P}$ Hubbard, 'Geographies of studentification and purpose built student accommodation: leading separate lives? (2009) 41 Environment and Planning A 1903, p 1904.
} 
by credit which has become the norm for the servicing of high-consumption student lifestyles. ${ }^{16}$ There is a growing controversy surrounding the cost of PBSA,${ }^{17}$ especially as providers benefit from lower planning requirements regarding room size and there is no requirement for a contribution to the provision of social housing. Local authorities have been keen to grant permission for blocks of PBSA as national planning policy requires local authorities to account for the housing need of students in local plans. Student housing can also be counted towards housing delivery targets, as PBSA frees up existing housing for the local population. ${ }^{18}$

From the perspective of universities, private providers of PBSA are important in the competitive higher education market. As undergraduate tuition fees are virtually identical between institutions, universities must find other ways to encourage students to choose them. Halls of residence, and the facilities provided within, are therefore an important part of the package offered. Universities need to guarantee places in halls of residence to first year students in order to compete, and students who are unable to secure places in halls prior to commencing university are seen to be at a disadvantage. ${ }^{19}$ Real estate is clearly important to universities, but it is not their core business, or area of expertise. The acquisition and development of new halls of residence coupled with the refurbishment and maintenance of existing student accommodation can be a burden. The result of this has been that the new growth in PBSA has been led by private providers rather than universities. According to the British Property Federation, there were 602,000 purpose-built bed spaces available to students for the start of the $2017 / 18$ academic year and 43 per cent of these beds were provided by the private sector. ${ }^{20}$ Although currently less than 50 per cent of students live in privately owned PBSA, the private sector

\footnotetext{
${ }^{16}$ Above $\mathrm{n} 2$ (Chatterton).

${ }^{17} \mathrm{R}$ Hall, 'Autumn of student activism begins over rising cost of university halls' (The Guardian, 25 October 2019) available at https://www.theguardian.com/education/2019/oct/15/autumn-of-student-activism-beginsover-rising-cost-of-university-halls.

18 Ministry of Housing, Communities and Local Government National Planning Policy Framework (February 2019).

${ }^{19}$ Above $\mathrm{n} 12$.

${ }^{20} \mathrm{R}$ Hanna British Property Federation Policy position - selective licensing on purpose built student accommodation available at https://www.bpf.org.uk/what-we-do/bpf-policy-position-selectivelicencing-pbsa.
} 
are starting to replace universities as the main providers. According to Cushman Wakefield, in 2018 77 per cent of new student beds were provided by private providers. ${ }^{21}$ The need to market desirable accommodation without owning and managing this accommodation requires formal relationships between the private providers and the universities. This relationship generally takes the form of a nomination agreement whereby the university agrees to fill a certain number of student beds for the provider in return for some involvement in rent setting and other operational matters.

The second stage of student housing, the move into shared private rental housing, has led to what many have termed 'studentification' of specific residential areas close to universities. Studentification is a process whereby a large number of students move into a residential area creating social, cultural, economic and physical effects. ${ }^{22}$ Concerns expressed by local residents about anti-social behaviour of students have led many local authorities to impose restrictions on the conversion of further family dwellings into HMOs. Permitted development means that changing a 'dwelling house' ${ }^{23}$ into a 'house in multiple occupation' ${ }^{24}$ does not require an application for planning permission. However, local planning authorities can use Article 4 of the Town and Country Planning (General Permitted Development) Order 1995 to override this blanket consent if it feels that there are excessive numbers of HMOs. ${ }^{25}$

This paper begins with an outline of the main problems faced by students living in first the PRS, and then the PBSA, and assesses the extent to which current law and regulation succeeds in dealing with these difficulties. The second section examines debates around the nature of tenancies by firstly considering the extent to which the law treats tenancies as contracts rather than property and secondly how consumer protections can, and already do, assist tenants. The third section discusses how the power relationship between consumers and traders and landlords and tenants inhibits access

\footnotetext{
${ }^{21}$ Cushman Wakefield, UK Student Accommodation Report 2018/19 (2019) p 9.

${ }^{22}$ Above n 9, p 149.

${ }^{23}$ Town and Country Planning (Use Classes) (Amendment)(England) Order 2010/653.

24 Ibid.

25 Town and Country Planning (General Permitted Development)(Amendment)(England) Order $2010 \mathrm{SI}$ 2010/654, Art 4(1).
} 
to legal redress and how the relationship between student landlords and student tenants is particularly unbalanced. It further considers how issues of access to justice prevent tenants from benefitting from the legal protections designed to help them. The paper concludes by arguing that whilst viewing tenancies as consumer contracts might be a useful approach to enhancing protections for student tenants, particularly by providing access to an ombudsman as a means of redress, the power relationships between students and their landlords mean that these measures alone are insufficient. Increased licencing and monitoring by local authorities, and better collaboration with universities in the monitoring and enforcement of standards would do more to improve students' experience of housing.

\section{PROBLEMS IN WITH STUDENT HOUSING}

\section{(a) Houses of multiple occupation in the PRS}

Approximately 30 per cent of students, particularly those in their second and third year of study, live in shared houses rented from private landlords. ${ }^{26}$ These houses are typically let on a 10-12 month assured shorthold tenancy (AST). The main areas of concern for assured shorthold tenants in the PRS as a whole, are security of tenure and repair. Whilst the fact that landlords are able to require tenants to leave at the end of their fixed term without fault or explanation is problematic for many tenants in the sector, particularly families, this is not really an issue for students who often want to leave at the end of the year. ${ }^{27}$

More of a concern for students, is the poor state of repair of their rented homes. Homes in the private rented sector are in a worse state than any other tenure with a third failing to meet the Decent Homes Standard that was set by the Government for council and housing association accommodation. ${ }^{28}$

\footnotetext{
${ }^{26}$ Above $\mathrm{n} 6$.

${ }^{27}$ Above $\mathrm{n} 12$.

${ }^{28}$ The Decent Homes Standard requires homes to be: free from any hazard that poses a serious threat to health or safety; to be in a reasonable state of repair; have reasonably modern facilities; have efficient heating and insulation (Ministry of Housing, Communities and Local Government A Decent Home: Definition and Guidance for Implementation (2006)).
} 
According to Shelter, over six in ten renters have experienced at least one of the following problems in the previous 12 months: damp, mould, leaking roofs or windows, electrical hazards, animal infestation and gas leaks. ${ }^{29}$ As much of the housing stock is old, particularly in the PRS where 49 per cent of dwellings pre date 1945 (as opposed to 17 per cent of social homes), ${ }^{30}$ there are often problems with heating, damp proofing, windows and insulation. The most serious problems, Category 1 Hazards, ${ }^{31}$ occur with more than twice the frequency in the PRS as compared to the social housing sector. ${ }^{32}$ There is no data specific to the state of repair of student housing, but it is likely that houses occupied by students face the same problems as the rest of the housing in the PRS. Repair of rented accommodation is not an area devoid of law, quite the contrary there is a confusing array of statutes that can be invoked to address some of the problems faced by tenants. Some of these protections enable the tenant to take direct action against the landlord and others require the tenant to report the landlord's failing to the local authority.

The Housing Health and Safety Rating System (HHSRS) gives local authorities the power to assess the condition of housing in the PRS and identify potential risks and hazards to health and safety arising from any deficiencies identified in dwellings. ${ }^{33}$ The most serious types of hazard are categorised as 'Category 1 ' hazards, the less serious as 'Category 2' hazards. The extent to which local authorities use these powers is extremely variable. In a study of London councils carried out by Pidgeon in 2016 a quarter of councils had failed to bring a single prosecution in 2015/16 whereas one council, Newham, was responsible for more than two-thirds of all prosecutions. ${ }^{34}$ There was also significant variation in terms of inspections, with some councils inspecting one in 10 private rented properties and others

\footnotetext{
${ }^{29}$ Shelter Happier and Healthier: Improving Conditions in the Private Rented Sector (September, 2017).

${ }^{30}$ Ministry of Housing, Communities and Local Government English Housing Survey 2016-17 Live Data Table DA1101 (July 2018).

${ }^{31}$ Housing Act 2004, s 2 and Housing Health and Safety Rating System (England) Regulations 2005.

${ }^{32}$ Ministry of Housing, Communities and Local Government English Housing Survey Headline Report 2017-18 (January 2019) 2.16.

${ }^{33}$ Housing Health and Safety Rating System (England) Regulations 2005.

${ }^{34} \mathrm{C}$ Pidgeon Rogue Landlords in London: a Survey of Local Authority Enforcement in the Private Rented Sector (October 2016) available at https://www.london.gov.uk/sites/default/files/rogue landlords in london a survey of local authority enforcement in the private rented sector.pdf.
} 
only inspecting one in every 600 properties. ${ }^{35}$ Some councils are proactive in inspecting properties and even instigate mandatory licensing for all privately rented housing, while others may wait and respond to complaints from tenants. ${ }^{36}$

Many student houses will be Houses of Multiple Occupation (HMOs), a class of housing singled out for additional regulation on the basis of the increased risk to the health and safety of occupants. ${ }^{37} \mathrm{HMOs}$ are properties that are occupied by more than one household. ${ }^{38}$ Local housing authorities have considerable powers to intervene where HMOs are unsatisfactory in terms of repair and maintenance. Powers include undertaking work where the manager of an $\mathrm{HMO}$ fails to do so. Mandatory licencing applies to all HMOs occupied by five or more people. ${ }^{39}$ Where a licence is required, both the licence holder and proposed manager must be shown to be 'fit and proper' people, and the management arrangements must be satisfactory. There are a number of mandatory conditions such as production of gas safety certificates, smoke alarms and the safety of electrical appliances and furniture. Failure to obtain a licence, or breach of the conditions, is a criminal offence punishable by a fine. Enforcement powers have been enhanced by the Housing and Planning Act 2016, to include banning of landlords and letting agents where they have been convicted of a serious offence. ${ }^{40}$

Whilst the powers available are considerable, they can only be exercised when problem properties have been identified. Local housing authorities may be proactive or reactive. Proactive measure include: identifying problems by carrying out manual street surveys, sharing information across different agencies or carrying out geographic information system mapping or thermal imagining aerial

\footnotetext{
35 Ibid.

${ }^{36}$ Newham London Private Rented Property Licensing Guide for Landlords and Managing Agents available at https://www.newham.gov.uk/Pages/Services/Private-rented-property-licensing.aspx.

37 M Cairns 'Houses in multiple occupation (HMOs)' (2003) 7 L\&T Review 9.

${ }^{38}$ Housing Act 2004, ss 254-260 and the Licencing of Houses in Multiple Occupation (Prescribed Descriptions)(England) Order 2018 SI No 221.

${ }^{39}$ The Licencing of Houses in Multiple Occupation (Prescribed Descriptions)(England) Order 2018 SI No 221.

${ }^{40}$ Housing and Planning Act 2016, Part 2 Chapter 2.
} 
mapping ${ }^{41}$ Reactive approaches involve responding to complaints from residents or tenants. ${ }^{42}$ The discretion afforded to local authorities creates a postcode lottery of enforcement when it comes to housing standards in the private rented sector. ${ }^{43}$ Shelter have identified a number of examples of good practice including the work that Manchester City Council and Leeds City Council have done with their local universities to improve the standards of student homes. ${ }^{44}$

In addition to the public powers outlined above, tenants also have a range of statutory protections that they can use to try to improve the quality of their accommodation. The main protections for tenants of short leases ${ }^{45}$ in the PRS can be found in the Landlord and Tenant Act 1985 (LTA). The recently enacted Homes (Fitness for Human Habitation) Act 2018 amends the LTA 1985 to introduce a new section 9A, section $9 \mathrm{~B}$ and section $9 \mathrm{C}$ and amends section 10, for England. ${ }^{46}$ The LTA s9A provides an obligation that the dwelling is fit for human habitation at the time of the grant and that the landlord will keep it fit for human habitation. A home will be unfit if it is not reasonably suitable for occupation in its current condition as a result of being defective in one of the following areas: repair; stability; freedom from damp; internal arrangement; natural light; ventilation; water supply; drainage and sanitary conveniences; facilities for preparation and cooking of food and for the disposal of waste water; any other matter or matters that may amount to a Category 1 Hazard. Whereas previously where a Category 1 Hazard was identified, only the local authority could take action (and rarely did so), under the new law the tenant can take direct action in court. The new provisions enacted by the Homes (Fitness for Human Habitation) Act 2018 enhance existing obligations imposed

\footnotetext{
${ }^{41}$ Ministry of Housing, Communities and Local Government Rogue Landlord Enforcement Guidance for Local Authorities (April 2019).

42 Ibid.

${ }^{43}$ TJ Simock and N Mykkanen The Postcode Lottery of Local Authority Enforcement in the Private Rented Sector (Residential Landlords Association, 2018) available at https://research.rla.org.uk/wp-content/uploads/postcode-lottery-enforcement-prs.pdf.

${ }^{44}$ M Mackenzie What Works? Tackling Rogue Landlords and Improving the Private Rented Sector (Shelter, September 2013); H Gousy Safe and Decent Homes: Solutions for a Better Private Rented Sector (Shelter, 2014).

${ }^{45}$ A short lease is a lease of less than seven years (Landlord and Tenant Act $1985 \mathrm{~s}$ 13(1)).

${ }^{46}$ These new provisions apply to tenancies entered into after 20 March 2019 and all periodic tenancies that are in existence on 20 March 2019 after 12 months. The provisions will therefore apply to most applicable tenancies by 20 March 2020.
} 
on landlords by s11 of the LTA 1985 to keep the structure and exterior and gas, electricity and water installations in repair. Problems such as mould were rarely caught by s11, leading tenants of virtually uninhabitable houses without a remedy. ${ }^{47}$ The Homes (Fitness for Human Habitation) Act 2018 in theory prevents a landlord for letting a property that is unfit for human habitation by requiring that a dwelling be fit for human habitation at the time of the grant of the tenancy and that it be kept fit for habitation for the duration of the term. ${ }^{48}$ However, in reality the landlord of an unfit property will only be required to remedy defects when notified in writing by the tenant and then only within a 'reasonable time'. This can leave tenants with relatively long periods of time living in unfit homes. Increasing the power of tenants has been applauded by campaigners including charities and housing lawyers and is clearly an important step forward. However, giving tenants additional legal powers does not necessarily lead to improvements in the condition of the property. As we will see in the third section of this paper, the power relationship between landlords and tenants, particularly vulnerable or young tenants, can prevent the effective use of these rights.

The Homes (Fitness for Human Habitation) Act 2018 will be a useful tool in the armoury of tenants with regard to repair. However, tenants may still choose to involve the local authority in dealing with problem landlords. One of the advantages of these provisions is that they do not require the landlord to be notified and they impose no financial risk on the tenant. As we will see in the third section of this paper, notification of a want of repair to a landlord may be a barrier to some tenants, particularly students. However, the ease with which students can obtain the assistance of the local authority will depend on where they live. In most instances the local authority will have delegated their responsibilities to their local environmental health officers. Encouraging local housing authorities to take action may require the tenant or their adviser to push quite hard and if necessary to approach

\footnotetext{
${ }^{47}$ Quick v Taff Ely BC [1986] QB 809.

${ }^{48}$ Landlord and Tenant Act 1985 s 9 A inserted by the Homes (Fitness for Habitation) Act 2018 s 1(3).
} 
local councillors or the local Member of Parliament. ${ }^{49}$ The need for a forceful approach is a further barrier for young and inexperienced tenants.

\section{(b) The purpose built student accommodation sector}

Currently around 30 per cent of students live in either university owned or private halls of residence with about two-thirds in accommodation owned by their university and a third owned by private providers. ${ }^{50}$ Unlike students occupying HMOs in the PRS, students occupying rooms in the PBSA sector have not tended to face problems with mice and mould. However, at the start of the 2019/20 academic year 1,500 students were unable to move into their halls of residence because their accommodation was unfinished. ${ }^{51}$ Some students were temporarily accommodated in other halls of residence while some were left living in hotels without access to kitchens or facilities for washing clothes. In Bristol, delays in completion meant that students were living in Newport in South Wales while they waited for their accommodation to be completed. ${ }^{52}$

The extent of protections afforded to occupiers of the PBSA depend, to some extent, upon the provider of the accommodation. Where the PBSA provider is not a university, the occupier will usually be a tenant and the provider will be subject to the licencing regime applicable to $\mathrm{HMOs} .{ }^{53}$ Where PBSA occupiers are tenants they will occupy under an AST like students living in the PRS and will have the benefit of the same statutory protections relating to repair. ${ }^{54}$ The behaviour of private providers of PBSA is to some extent governed by the ANUK/ Unipol 'National Code of Standards for Larger Developments for Student Accommodation Not Managed and Controlled by Educational

\footnotetext{
49 J Luba C O'Donnell and G Peaker, Housing Conditions Tenants' Rights (London: Legal Action Group 6 ${ }^{\text {th }}$ edn, 2019).

${ }^{50}$ Above $n 6$.

${ }^{51}$ B Ellery, R Bennett and N Wollcock 'Universities under Fire as Accommodation Crisis Hits Students' (The Times, 7 October 2019) available at https://www.thetimes.co.uk/article/universities-under-fire-asaccommodation-crisis-hits-students-3vp2wn8zp.

${ }^{52}$ A Ross 'Bristol University Students Live in Wales - Because There's No Space in Bristol Halls' available at (Bristol Post, 11 September 2019) available at https://www.bristolpost.co.uk/news/bristol-news/bristoluniversity-students-live-wales-3306343.

53 Housing Act 2004, Schedule 14, para 4(1).

${ }^{54}$ See discussion on repair regarding the PRS above.
} 
Establishments'. ${ }^{55}$ Accordingly to the British Property Federation, 90 per cent of private providers of PBSA have signed up to this code. ${ }^{56}$ The code contains a number of provisions relating to delayed delivery of accommodation, including a requirement that the manager inform the future tenant at the earliest possibility of the likelihood of delay and from whom they can access help. The provider is also required to notify the National Codes Administrator (NCA). Where the room is not ready for occupation on the date that the tenancy begins a suitable alternative room must be provided. There are additional provisions relating to payment of rent and reimbursement of out-of-pocket expenses. ${ }^{57}$ However, these provisions did not prevent students due to start at university in September 2019 from being accommodated miles from the university campuses in budget hotels. There is also no way of compensating for the loss of the shared experiences of the early weeks of university that are considered so significant for forming social relationships. ${ }^{58}$ Unipol investigated late delivery of student housing and have made proposals to improve the code to include: a tighter definition of 'late buildings', a requirement for educational institutions to be informed where buildings are likely to be late, 'no quibble' compensation payments and the ability for students to be released from their contract if the building is not due to be completed on time. ${ }^{59} \mathrm{It}$ is all too easy for providers of PBSA to blame contractors for late completion and delays in completion are, of course, a fact of life in the construction industry. However, PBSA providers need to be compelled to be honest and transparent with students where contractors are clearly not going to complete on time. Unipol have therefore created a new protocol for late developments. This protocol requires members to seek written assurances from developers and contractors that the accommodation will be ready for completion at

\footnotetext{
${ }^{55}$ ANUK/ Unipol The National Code of Standards for Larger Developments for Student Accommodation Not Managed and Controlled by Educational Establishments (2006).

${ }^{56}$ British Property Federation BPF Policy Position - Selective Licencing on Purpose Built Student Accommodation.

${ }^{57}$ Above $n 55$ para 3.7-3.9.

${ }^{58} \mathrm{~K}$ Chow and $\mathrm{M}$ Healey 'Place attachment and place identity: First-year undergraduate's making the transition from home to university' (2008) 28(4) Journal of Environmental Psychology 362.

59 Unipol Result of an investigation into late buildings within the ANUK/Unipol Codes available at: https://www.nationalcode.org/news/result-of-an-investigation-into-late-buildings-within-the-anukunipolcodes.
} 
the start of the tenancy agreement. Where a negative response is received the member will be required to take action to communicate with students. This may enable students to look for alternative accommodation. This protocol will also strengthen any legal action students may bring should the accommodation be delivered late and the provider fail to deliver on their backup plan. The protocol also requires that websites used to advertise the accommodation will need to make it clear that the accommodation may not be delivered on time and what action will be taken if it is not delivered.

One of the problems with supporting students living in the PBSA is that universities, who have a duty of care for the wellbeing of their students, may have no relationship at all with private providers of PBSA. In some instances, the university will have a contractual relationship with the provider via a nomination agreement. However, some blocks of PBSA are built without any relationship between the provider and the institution that supplies the students. Where there are significant failings in the PBSA, such as late delivery of accommodation or damage by fire universities will, quite rightly, be called upon to assist students. However, in the instances where there is no nomination agreement they have very little influence on the behaviour of the provider or even a channel of communication. The public and the press will call upon universities to explain any failings, but there are insufficient mechanisms available to universities to control issues such as timely delivery. Unipol's proposed amendments the code, if instigated, will at least ensure that universities are informed of potential late delivery of accommodation.

Local planning authorities benefit from PBSA is terms of meeting their housing delivery targets and could play a stronger role in shaping the relationship between providers of PBSA, universities and students. In London, the Draft London Plan requires providers of PBSA to enter into a nomination agreement with one or more specified higher education institutions. ${ }^{60} \mathrm{~A}$ requirement for providers of

\footnotetext{
${ }^{60}$ See website available at https://www.london.gov.uk/what-we-do/planning/london-plan/new-londonplan/draft-new-london-plan/chapter-4-housing/policy-h17-purpose-built-student-accommodation.
} 
PBSA to enter into a nomination agreement enables an ongoing relationship between the provider and the university. In cases of new PBSA the university is able to require updates regarding completion of the accommodation to help prepare students for potential delays in delivery and to better plan for alternative accommodation and additional support such as transport from other places.

\section{CONSUMER PROTECTION}

\section{(a) The AST as a species of contract}

Both the government and the Law Commission acknowledge that the PRS does not always provide tenants with the best home. Consultations and proposals for reform have been framed as increasing consumer protections for private rented tenants. For example, the Law Commission in their 2006 report entitled 'Renting Homes' ${ }^{61}$ recommended 'a new "consumer protection" approach which focuses on the contract between the landlord and the occupier (the contract-holder), incorporating consumer protection principles of fairness and transparency ${ }^{\prime 62}$ and, in a consultation announced in 2018, the Government proposed longer tenancies as a form of consumer protection. The Law Commission's narrative on consumer protection emphasises the need for tenants to have a written statement of their contract, setting out the rights and obligations of the parties. The Law Commission states that 'many landlord-tenant disputes currently arise from ignorance' ${ }^{63}$ However the main problems of tenants in the PRS relate to repair, which is largely the result of landlords failing to comply with their statutory obligations, rather than tenants failing to understand the terms of the contract.

In order to consider a tenancy as a consumer contract, it is first necessary to consider the tenancy agreement as a species of contract. Leases are often thought of as a hybrid of property and contract, 'a lease is a bilateral contract which as a general rule, confers an estate in land capable of binding third

\footnotetext{
${ }^{61}$ Law Commission Renting Homes the Final Report: Volume 1 (Law Com No 297, May 2006).

62 Ibid para 1.5.

${ }^{63}$ Above $\mathrm{n} 61$ para 1.16.
} 
parties'. ${ }^{64}$ The grant of a lease involves the creation of an estate in land; it is undeniably a proprietary interest. ${ }^{65}$ However, short term commercial and residential leases include numerous covenants which require an ongoing relationship between the parties that is very much in the nature of a contractual relationship. The debate surrounding the extent to which leases should properly be considered contractual has involved commentators from a number of common law jurisdictions. ${ }^{66}$ Effron argues that although landlords surrender a right to occupancy they remain concerned about the maintenance and use of the premises and tenants expect a certain standard of maintenance and amenities. He argues that the 'grant' in the lease is insignificant compared the multitude of covenants within the lease.$^{67}$ On this basis, the relationship of landlord and tenant in the PBSA feels strongly contractual, particularly because of the numerous facilities provided. However, the relationship of landlord and tenant in the PRS is much less akin to a consumer relationship with few, if any, services provided and landlords sometimes refusing to undertake even the most necessary repairs.

In England, a number of cases have also demonstrated the acceptance by the courts of the contractual nature of leases. Key judicial decisions have held that: a purely contractual lease can be created where a landlord has no estate in land ${ }^{68}$, the contractual doctrine of frustration can apply to leases ${ }^{69}$ and a tenant may, in certain circumstances, repudiate a lease ${ }^{70}$. Repudiation may prove useful in the severest cases of breach of repairing obligations but it is unlikely to help students facing delayed completion of halls of residence. Delay will only amount to a repudiation 'where the delay gives rise to the inference that the defaulting party does not intend to be bound by the terms of the contract' ${ }^{71}$

\footnotetext{
${ }^{64} \mathrm{C}$ Harpum, S Bridge and M Dixon Megarry and Wade the Law of Real Property (London: Sweet and Maxwell, 2012) p 743.

${ }^{65}$ A lease is one of only two legal estates capable of being created, Law of Property Act 1925, s 1(1).

66 J Morgan 'Leases: property, contract or more?' in M Dixon (ed), Modern Studies in Property Law (London: Hart, 2009); K Gray 'Property in thin air' (1991) 50 CLJ 252; J Effron 'The contractualisation of the law of leasehold: pitfalls and opportunities' (1988) 14 Monash UL Rev 83; J Brock and J Phillips 'The commercial lease: property or contract?' (2001) 38 Atlanta Law Rev 989.

67 Ibid, p 83.

${ }^{68}$ Bruton v London and Quadrant Housing Trust [2000] 1 AC 406.

${ }^{69}$ Hammersmith and Fulham LBC v Monk [1992] 1 AC 478

${ }^{70}$ Hussein v Mehlman [1992] 2 EGLR 87.

${ }^{71}$ H G Beale Chitty on Contracts (London: Sweet \& Maxwell, 33 ${ }^{\text {rd }}$ edn, 2012) pp 37-220.
} 
Unipol propose including a right to be released from a PBSA contract in their updated code. ${ }^{72}$ However, repudiation is unhelpful to students unless there are unfilled rooms in other suitable halls for them to move into on termination of their contract.

\section{(b) Consumer protection law and ASTs}

Having established the contractual nature of leases it is necessary to consider the extent to which in theory and in practice a tenancy may be considered a 'consumer contract' and the potential benefits of viewing a tenancy in this way. Tenants, like consumers, are often presented with their contract as a non-negotiable fait a compli. Contract law alone does not provide adequate protection for tenants or consumers as both lack the bargaining power necessary to negotiate a good deal. This is particularly the case for tenants, as whilst consumers may be able to obtain a good deal through the market, the shortage of private rented housing prevents tenants from shopping around. Furthermore, students renting in the PRS are often young and inexperienced. Like consumers, tenants are also unlikely to read the contract that they sign, and if they do read the contract it is likely that it will be fully understood. ${ }^{73}$ With these similarities between tenants and consumers in mind, a consumer approach appears to have something to offer. In fact, it could be argued that an assured shorthold tenancy is so far from a freely negotiated contract that a regulatory rather than a contractual point of view is more appropriate. Brownsword argues that consumer contracts are regulated to such an extent that contract law now has nothing to do with it. ${ }^{74}$

There are a number of places in the contractual process where consumer law may intervene. At the pre contract stage consumer protection law may improve the transparency of the bargaining process. The common law has for a long time intervened where onerous terms are hidden in small print acknowledging the practical reality that consumers often do not read the contracts into which they

\footnotetext{
72 Above $n 61$.

${ }^{73}$ R Lee The Private Rented Sector: The Regulatory Landscape (CMPO, Working Paper No 06/148, 2006).

${ }^{74} \mathrm{R}$ Brownsword 'Regulating transactions: good faith and fair dealing' in G Howells and R Schulze (eds)

Modernising and Harmonising Consumer Contract Law (Munich 2009) p 89-113.
} 
enter. ${ }^{75}$ With regard to tenancies, the Law Commission acknowledged that terms may be hidden in tenancies and the meaning of certain terms may be unclear and therefore suggested the provision of model contracts which landlords and letting agents would be encouraged to use. These would set out the terms of the contract in clear English and would provide explanations of what was meant by the key terms and the implications of these terms for both the landlord and the tenant. ${ }^{76}$ The Government has provided freely available template tenancies for use by landlords ${ }^{77}$ but there is no evidence as to how frequently these are used. Furthermore, with regard to repair specifically, the terms of the contract are largely irrelevant as landlords cannot contract out of the statutory obligations of the LTA 1985. This insertion of implied terms regarding repair is an example of the sort of regulatory intervention that leads Brownsword to argue against viewing consumer contracts as contracts at all. Even without a mandatory form of tenancy agreement, the fact that the parties control little more than the duration of the tenancy and the rent, takes the assured shorthold tenancy a long way from the notion of 'freedom to contract'.

With regard to protection within the contract itself, the Consumer Rights Act 2015 (CRA) includes provisions with regard to transparency ${ }^{78}$ and unfair terms. The Act regulates relationships between consumers and traders. A 'trader' is defined as "a person acting for purposes relating to that person's trade, business, craft or profession, whether acting personally or through another person acting in the trader's name or on the trader's behalf" ${ }^{\prime 79}$. With regard to student housing, the CRA will apply to tenancies in the PBSA sector as the provider is clearly a 'trader'. However, the position in the PRS is less clear. Where ASTs are produced by letting agents these agreements will need to be CRA compliant, as a letting agent is clearly a trader. However, where the so called 'hobby landlord' ${ }^{80}$ does

\footnotetext{
${ }^{75}$ See for example, Thompson v London Midland and Scottish Railway Co [1930] 1 KB 41, Thornton v Shoe Land Parking [1971] 2 QB 163 and Interfoto Picture Library Ltd v Stiletto Visual Productions Ltd [1988] 2 WLR 615.

${ }^{76}$ Above n 69.

77 Department for Communities and Local Government, Model Agreement for an Assured Shorthold Tenancy and Accompanying Guidance (February 2016) available at https://www.gov.uk/government/publications/model-agreement-for-a-shorthold-assured-tenancy. ${ }^{78}$ s 68(1).

${ }^{79}$ Consumer Rights Act 2015, s.2(2).

${ }^{80}$ Law Commission Renting homes the final report: Volume 1 (Law Com No 297, 2006).
} 
not engage the services of a letting agent, it is unlikely that he or she would be viewed as a 'trader' for the purposes of the act. Under the Act, a term is transparent, 'if it is expressed in plain and intelligible language and (in the case of a written term) is legible' ${ }^{81}$ Where there is a failure to fulfil the requirement for transparency the Act provides, 'if a term in a consumer contract, or a consumer notice, could have different meanings, the meaning that is most favourable to the consumer is to prevail'.$^{82}$ Under the CRA 2015, 'a term is unfair if, contrary to the requirement of good faith, it causes a significant imbalance in the parties' rights and obligations under the contract to the detriment of the consumer' ${ }^{83}$ Where a term is found to be unfair it will not bind the consumer. ${ }^{84}$ The unfairness provisions of the CRA may assist students living in the PBSA sector. According to the CMA, potentially unfair terms include: unreasonably high charges for permission (for example keeping pets); terms that require tenants to pay charges that can be set at the trader's discretion or varied unilaterally; terms that require the tenant to use a particular third party for provision of energy or telecommunications; standard charges that do not reflect the landlord's loss; longer notice periods for ending the tenancy; fees to items that would not usually attract a charge. ${ }^{85}$ The nature of the product/ service provided by landlords is such that it may be argued that all landlords, whether making their living from rental income or merely topping up their pension, should be governed by the statutory standards set out in the CRA.

In addition to the consumer contract law protections considered above, public law protections may be invoked to protect consumers in the form of quality standards/ bans, regulation though registration and licencing, consumer access to information and self-regulation and codes of practice. Imposition of minimum standards backed by suitable enforcement action is one way in which public law can intervene to protect consumers. One such approach is an MOT style inspection and certification of private rented housing. Such a scheme has been proposed by some commentators as the only way to

\footnotetext{
${ }^{81} \mathrm{~s} 64(3)$.

${ }^{82}$ s $69(1)$.

83 s 62(4).

${ }^{84}$ Consumer Rights Act 2015, s 62(1).

${ }^{85}$ Competition and Markets Authority Guidance for lettings professionals on consumer protection law (2014).
} 
ensure that housing is fit for occupation at the commencement of the term. ${ }^{86}$ Registration requirements may merely require the trader to be listed on a register or may, in the case of sectors which might be considered higher risk, require licensing or even evidence of competence through qualification. In this case sanctions can be imposed merely for failure to comply with the registration requirements without the need for consumers to demonstrate harm. With regards to housing, in England, unlike other parts of the UK, currently only HMOs are licenced. ${ }^{87}$ There have been calls for compulsory licencing ${ }^{88}$ but these have to date been ignored by the Government who have chosen to focus on 'rogue landlords' ${ }^{89}$ Compulsory training for landlords has also been resisted by Westminster, whereas in Wales landlords must undertake training to ensure an understanding of the rights and responsibilities of landlords and tenants and comply with a code of practice. ${ }^{90}$ Renting out a house is a complicated business, it is estimated that there are around 50 Acts of Parliament and 70 sets of regulations that apply to the PRS. ${ }^{91}$ The effectiveness of licensing and compulsory training is contested. The efficacy of licencing schemes appears to depend upon the way that the register is used $^{92}$ and any such scheme needs to be supported by enforcement action. The costs of licencing, landlord training and quality certification is of major concern. It can be argued that costs might impede competition by creating barriers to market entry or that costs of registration are likely to be passed onto the consumer or may result in exodus from the market. A detailed consideration of the funding

\footnotetext{
${ }^{86} \mathrm{~J}$ Rugg and D Rhodes The evolving private rented sector: its contribution and potential (2018) available at: http://www.nationwidefoundation.org.uk/wp-content/uploads/2018/09/Private-Rented-Sector-report.pdf. 87 In Scotland there has been compulsory registration since 2006. In Wales registration became compulsory in November 2016. Landlords must then either obtain a licence or use licensed managing agents. Those seeking a licence must pass checks to ensure they are fit to let property, undergo training and comply with a code of practice. Northern Ireland has a national registration scheme but licences are only required for HMOs.

88 J Rugg and D Rhodes The Private Rented Sector: its Contribution and Potential (York Centre for Housing Policy University of York 2008) xxiii.

${ }^{89}$ Above $\mathrm{n} 41$ and Ministry of Housing, Communities and Local Government Rogue Landlord Database Reform Widening Access and Considering the Scope of the Database of Rogue Landlords and Property Agents (July 2019)

${ }^{90}$ Welsh Government Code of Practice for Landlords and Agents licenses under Part 1 of the Housing (Wales) Act 2014 (October 2015).

${ }^{91}$ London Assembly Housing Committee At Home with Renting: Improving Security for London's Private Renters. (Greater London Authority, 2016) available at https://www.london.gov.uk/sites/default/files/at home with renting march 2016.pdf.

92 House of Commons Housing, Communities and Local Government Committee Private Rented Sector Fourth Report of Session 2017-19 (17 April 2018).
} 
options for such proposals is outside the scope of this article, but an incentive such as text deduction of the costs of undertaking an inspection or Mortgage Interest Tax Relief, as has been provided in Ireland, would certainly be an option worthy of further consideration. ${ }^{93}$

\section{(c) Enforcement of consumer protection}

Consumer protection law may be enforced privately or publically, collectively or individually. Often the problem faced by consumers is not that there is no law to protect them but rather that enforcing the law is too complicated or costly. Private enforcement of consumer law through the courts is unpopular due to inconvenience, delay and both financial and emotional cost. The organisations against who consumers seek to enforce their rights are likely to be better resourced and more experienced. Collective enforcement can overcome some of these issues as consumers working together as a group may have more sway than an individual acting alone. This section considers which types of enforcement are available to tenants as consumers and whether access to different methods of enforcement might assist students.

Currently tenants in the PBSA and the PRS will enforce their rights by bringing a claim in the county court. In most instances this will be under the small claims procedure which assumes litigants will be acting without legal advice. However, this is a complicated procedure and the Pre-Action Protocol for Housing Disrepair Cases envisages instruction of experts and completion of a Schedule of Disrepair. Legal aid may in theory be available if there is evidence that disrepair results in serious risk of harm to health, but often tenants may find they live in a 'legal aid desert' with no local lawyers available to do legal aid housing work. ${ }^{94}$ Research suggests that tenants do not use the courts as an enforcement mechanism. ${ }^{95}$ For students in both the PRS and the PBSA bringing an individual private claim against

\footnotetext{
${ }^{93} \mathrm{~T}$ Moore and R Dunning Regulation of the Private Rented Sector in England using Lessons from Ireland (Joseph Rowntree Foundation, 2017).

${ }^{94}$ The Law Society Parliamentary briefing housing legal aid deserts (2019) available at: https://www.lawsociety.org.uk/policy-campaigns/public-affairs/parliamentary-briefing/legal-aid-deserts/. ${ }^{95} \mathrm{M}$ Isaksen It's broke, let's fix it improving redress for private renters (2017) available at: https://www.citizensadvice.org.uk/Global/CitizensAdvice/Its\%20broke\%20lets\%20fix\%20it\%20\%20Citizens\%20Advice.pdf.
} 
a landlord using a court based procedure seems disproportionately difficult and time consuming for the sums of money likely to be involved.

Private individual enforcement is therefore unlikely to provide a solution for tenants in either the PRS or in PBSA. Collective enforcement would not be appropriate for students in the PRS as there are most likely no other tenants (save their housemates) to bring a collective action with. However, collective action could be a useful mechanism in PBSA. As we have seen, large numbers of students have been affected by systemic failings by providers of PBSA. The value of the individual claims may not be large but the total amount of these claims could be substantial. Whilst common in the US, collective enforcement is not a feature of UK consumer protection. The US system of 'opt out' class actions ensures that all those adversely affected will benefit from the litigation unless they choose not to. The UK takes a very different approach. In the UK, group litigation orders require claimants to issue their own claim and they are only be grouped together to the extent that the claims are managed collectively. Although the CRA 2015 has provided for some instances where 'opt-out' litigation can occur by amending the Competition Act 1998 into the Competition Appeals Tribunal this is only available for actions relating to breaches of competition law. For students in the PBSA where a private provider has failed to deliver, some form of collective action would be beneficial, as the individual claims are relatively small and having the litigation run by a single lawyer and a lead claimant would appear to be a practical approach. However, group litigation orders do not provide this desired collective approach, as each student has to seek out and find legal advice and instigate their own proceedings. For students who are inexperienced and often unfamiliar with the legal system this is extremely onerous.

The CMA can take enforcement action where a trader has inserted an unfair term in a tenancy agreement. The CMA's guidance on enforcement makes it very clear that the CMA aims to take a targeted approach. It seems likely, therefore, that resources will be targeted at large scale anticompetitive practice by lettings agents, rather than engaging in the minutiae of tenancy agreement 
clauses. Certainly, the CMA has successfully pursued estates agents for fee-fixing ${ }^{96}$, just as the Oft succeeded against lettings agents with regard to unfair commission clauses ${ }^{97}$. Unless lettings agents or landlords fear enforcement, they have little to lose from inserting an unfair provision into an agreement. Particularly, as the tenant may not read the agreement and, as we will see, is unlikely to take action beyond an initial complaint when problems result from the contract term.

\section{POWER AND JUSTICE}

This section looks beyond the strictly legal and procedural hurdles to access to justice considered in section 2 and considers the barriers to access to justice created by the power imbalance between students and their landlords.

\section{(a) Landlord and tenant power relations}

As we have seen, private law alone is not sufficient to provide effective protection for either consumers or tenants. This is in part because of the problems faced by consumers seeking to enforce their legal rights. One such problem is ignorance of the law. Identification that there is a legal problem, 'naming' is the first barrier to justice identified by Felstiner, Abel and Sarat ${ }^{98}$. According to Felstiner, Abel and Sarat the next barrier is 'blaming', which is where the victim identifies who is to blame. The final barrier is 'claiming' which is confronting the perceived wrongdoer and asking for a remedy. Only after these steps have been taken will the victim seek legal redress. There is, therefore, plenty of opportunity for a consumer or tenant to stop short of accessing the legal redress available and as a result litigation is unlikely, 'it is a practical truth that literally the last thing that the typical disgruntled consumer will do is to initiate litigation against a trader. Court proceedings take time and cost money, even if they are ultimately successful'. ${ }^{99}$ This phenomenon is sometimes referred to as 'rational

\footnotetext{
${ }^{96}$ CMA v Michael Christopher Martin [2020] EWHC 1751 (Ch).

97 Oft v Foxtons [2009] EWHC 1681.

${ }^{98}$ WLF Felstiner, RL Able and A Sarat 'The Emergence and Transformation of Disputes: Naming, Blaming, Claiming...' (1980) 15 Law \& Soc'y Rev 631.

${ }^{99} \mathrm{G}$ Howells and S Weatherill Consumer Protection Law (London: Routledge, $2^{\text {nd }}$ edn, 2005) p 47.
} 
apathy' and this state of mind is influenced by factors such as access to legal aid, litigation fees and civil procedure cost allocation. ${ }^{100}$

The Paths to Justice Survey undertaken in 1996 aimed to elucidate how the civil justice system might better serve the needs of the public. ${ }^{101}$ In this survey about seven percent of the total sample had experienced problems with rented accommodation and by far the most common problem for this group was getting the landlord to do repairs. ${ }^{102}$ In nearly 90 per cent of cases respondents who had problems with rented property had taken some action. In 69 per cent of cases this was direct contact with the landlord, in 37 per cent of cases advice was taken and in only 2 per cent of cases were legal proceedings instigated. Whilst it is reassuring that tenants were inclined to make contact with their landlord when there was a problem rather than merely ignore it, the success rate of 'self-helpers' in the survey was lower than 50 per cent. Success depended on 'the confidence, competence and persistence of the complainant and the intransigence of the other party involved in the problem'. ${ }^{103}$ It unsurprising that where there is a problem in a contractual relationship confidence, competence and persistence increase the chances of a successful resolution. However, dependence on the personality of the tenant is likely to be especially prejudicial to young tenants. Students are particularly vulnerable in this regard. In a study of young people living in private rented housing, Lister found that the majority of those interviewed had suffered problems with mould or damp and that none of the landlords had responded to the complaints made. ${ }^{104}$ One of the challenges faced in the PRS, and where it differs from PBSA, is that a tenancy in the PRS is heavily influenced by social relationships. Both landlords and tenants have expectations beyond those derived in contract or dictated by statute. For example, in her research Lister found that landlords sometimes expressed the view that tenants must

\footnotetext{
${ }^{100}$ WH Van Boom and MBH Loos 'Collective enforcement of consumer law: securing compliance in Europe through private group action and public authority intervention' in WH Van Boom and MBH Loos (eds) Collective Enforcement of Consumer Law in Europe. Securing Compliance in Europe Through Private Group Action and Public Authority Intervention (Zutphen: Europa Law Publishing, 2007) p 231.

101 H Genn Paths to Justice What People do and Think about Going to Law (Oxford: Hart, 1999).

10248 per cent.

${ }^{103}$ Above $\mathrm{n}$ 101, p 74.

104 J Rugg, D Rhodes and A Jones 'Studying a niche market: UK students and the private rented sector' (2002)

17(2) Housing Studies 289.
} 
perform certain obligations in return for the services which they were in any event legally obliged to perform. ${ }^{105}$ It is not only tenants who may be inexperienced, many landlords in the PRS are what have been referred to as 'hobby landlords' a term used to refer to landlords who own one or two properties and have ended up renting a property as a result of an inability to sell, inheritance or where moving in with a partner results in an extra property. ${ }^{106}$ Rather than relying on their legal right to repair tenants used social strategies to try to secure action from their landlords, their ultimate strategy being to leave at the end of the fixed term. ${ }^{107}$ A study of tenancy deposits carried out by Jones demonstrates that students were often aware of the law but unclear about how it worked. ${ }^{108}$ Three quarters of the students surveyed had not been informed about what they should do if there was a dispute even though half of students disagreed with the landlord and letting agent withholding as much of the deposit as they did and around a third ending up in dispute about the deposit. ${ }^{109}$ Of those that disputed the withholding of part of their deposit only a third used the free alternative dispute resolution service. The low uptake was a result of ignorance of the service or the perception that it was not worth the hassle. Over two thirds of students felt had limited or no confidence that ADR would lead to justice. ${ }^{110}$

Chisholm, Howden-Chapman and Fougere analysed 15 previous qualitative studies pertaining to how private tenants in England, the US, Australia and New Zealand responded to problems with their housing conditions using an analytical framework relating to three-dimensional power. ${ }^{111}$ They identified the three dimensions of power as; visible power, hidden power and invisible power. All three dimensions of power precluded tenants from successfully reporting problems with repair. The

\footnotetext{
${ }^{105} \mathrm{D}$ Lister 'Controlling Letting Arrangements in the Private Rented Sector' in D Hughes and S Lowe (eds) The Private Rented Housing Market (London: Ashgate 2007).

${ }^{106} \mathrm{E}$ Walsh 'Security of Tenure in the Private Rented Sector' in B MacFarlane and S Agnew (eds) Modern Studies in Property Law (London: Hart 2019) p 210.

${ }^{107}$ Above $n 104$.

${ }^{108} \mathrm{G}$ Jones 'The tenancy deposit protection scheme: the perspectives and experience of higher-education students' (2011) 14(3) JHL 64.

109 Ibid.

110 Ibid.

${ }^{111}$ E Chisholm, P Howden-Chapman and G Fougere, 'Tenant's Responses to Substandard Housing: hidden and Invisible Power and the Failure of Rental Housing Regulation' (2019) Housing, Theory and Society 1.
} 
first dimension of power, visible power, considered who wins and who loses in disputes over rental housing quality. In analysing the 15 studies it was clear that 'in many cases, tenants' desire for housing repairs or improvements conflicts with landlords' willingness to carry these out'. ${ }^{112}$ The second dimension of power, hidden power, showed that tenants often avoided asking for repairs as they did not think doing so was worth it. Finally, the third dimension of power, invisible power, was evidenced by tenants whose experiences of the sector were such that they lowered their expectations about acceptable standards. Whilst Chisholm et al's analysis suggests that tenants were often what Genn would call 'lumpers' (they didn't complain) this contradicts Genn's earlier findings that they often did complain, but frequently they did not succeed in resolving matters. The explanation for this discrepancy in findings may be that the English studies included in Chisholm's analysis were Lister's studies of young tenants who are perhaps less likely to complain than the tenant population as a whole. ${ }^{113}$

\section{(b) Access to justice}

We have established that tenants, and more specifically students, are reluctant to complain about tenancy issues. As we have seen in the research on power balance between landlords and tenants, legal proceedings are rarely instigated for breach of repairing obligations. ${ }^{114}$ Even where tenants wish to sue for breach of contract, or breach of the statutory obligations relating to repair, to do so without legal advice is daunting, and legal advice may simply not be available. Legal aid is only available where there is a 'serious risk of harm' arising from a deficiency in the tenant's home. ${ }^{115}$ Significant amounts of damp and mould may be covered but less significant issues will not. In any event, even where legal aid is in theory available a lawyer in the immediate area may not. The Law Society found that over a

\footnotetext{
112 Ibid 9.

${ }^{113}$ Above $\mathrm{n} 71$; Above $\mathrm{n} 104$.

${ }^{114}$ Above $\mathrm{n} 73, \mathrm{p} 74$.

115 Legal Aid, Sentencing and Punishment of Offenders Act 2012, Sch 1, para 35.
} 
third of the population of England and Wales live in a local authority with no housing legal aid providers. ${ }^{116}$

Problems with utilisation of the court system for dealing with consumer problems has long been acknowledged. Power relations between landlords and tenants, and more specifically between landlords and student tenants make litigation inappropriate. Self-regulation, whilst cheaper than public regulation has not provided students with the redress they require in either the PRS or the PBSA. In the PRS membership of a professional organisation/ accreditation scheme is voluntary and most landlords do not join one. ${ }^{117}$ In the PBSA sector on the other hand, most providers have signed up to a code of conduct. However, student complaints made to the NCA are relatively uncommon. ${ }^{118}$ There were only 50 complaints to the NCA in the first half of 2019 , a far lower number than students adversely affected by the late delivery of buildings alone. Although the code is clearly not providing much in the way of access to justice for students, it is carrying out a useful function in improving selfregulation of the sector. In response to problems caused by late delivery Unipol have investigated and amended the code. It is hoped that this will go some way towards prevention of problems for students in the future.

For students in the PRS, the government's proposal for compulsory membership of an ombudsman scheme may assist to some extent. ${ }^{119}$ Students have access to an ombudsman where they wish to complain about their Higher Education institution, but currently private tenants, unlike those living in the socially rented sector, have no access to an ombudsman service. Customer satisfaction with ombudsman schemes in the socially rented sector ${ }^{120}$ suggests that there is scope for such schemes to be useful for students. The most common complaints made to the Housing Ombudsman Service by

\footnotetext{
${ }^{116}$ The Law Society Parliamentary Briefing Housing Legal Aid Deserts (2019).

117 Ministry of Housing Communities and Local Government English Private Landlord Survey 2018 Main Report (2019).

${ }^{118}$ National Codes Annual Report 2019 available at: https://www.nationalcode.org/annual-report.

${ }^{119}$ Ministry of Housing, Communities and Local Government James Brokenshire announced overhaul of broken housing complaints system' press release (24 January 2019).

${ }^{120}$ The Housing Ombudsman Service (2019) The housing ombudsman annual report and accounts 2018-19.
} 
tenants in the social rented sector relate to repair. ${ }^{121}$ The more informal and less adversarial approach does appear to have some success with these issues in the social rented sector. However, there are number of key pitfalls to use of an ombudsman for student housing issues. Firstly, as we have seen, complaints made via the code have been relatively rare and from this we might deduce that students will be equally reluctant to complain to an ombudsman. Secondly, the lack of enforceability of any order made by the ombudsman may be problematic. This is particularly the case with landlords in the PRS who may not suffer the same reputational risk as a PBSA provider who could be 'named and shamed'. The ombudsman proposal also fails to take account of the particular situation of students and the power dynamic of landlords and student tenants. The ombudsman process is simply too slow and probably too complicated to prevent 'rational apathy'. From a practical perspective where the relationship between landlord and tenant has a duration of less than a year, no ex post approach is likely to be effective.

\section{CONCLUSION}

(a) Is a consumer law the solution?

Consumer protection law acknowledges the uneven nature of the relationship between the consumers and businesses and provides protections at various points in the process. The ethos of consumer protection law is therefore equally appropriate for tenants as other consumers as the inequality of bargaining power in both cases needs to be rebalanced. However, neither consumer contract law nor improved redress provide much benefit for student tenants.

In terms of the tenancy as a contact and the terms contained therein, the provisions of the Consumer Rights Act 2015 may assist students living in the PBSA in terms of ensuring that tenancy agreements are transparent and do not contain unfair terms. However, the CRA 2015 will have little if any impact on the PRS in which most landlords are private individuals rather than traders. It is argued that all

${ }^{121} \mathrm{lbid}$. 
landlords should be abound by the CRA 2015. The standard form of assured shorthold tenancy agreement provided by the government to improve the transparency of the contract between landlord and tenant in the PRS while well-meant is unlikely to have any significant impact. More helpful for students living in the PRS are the terms relating to fitness implied into the tenancy by the legislation.

The bigger problem for students as tenants is access to redress when problems arise. The inequality in the power relationship, particularly for young inexperienced tenants, the complicated nature of housing law, and the lack of access to specialist advice can leave students putting up with poor treatment from providers in both the PRS and PBSA sector. Self-regulation of the PBSA has to date not prevented delays in delivery of accommodation, and the mechanisms provided for complaint are relatively rarely used. Proposals by Unipol to take a more proactive approach are welcome as most providers of PBSA do sign up to the code. Students as individuals do not feel empowered to take action against providers of PBSA. This may be the result of rational apathy driven by the relatively short duration of their relationship with the PBSA provider and by the combination of the time take to complain combined with a lack of support in making a complaint. A requirement that private providers communicate regarding delays with education institutions as well as this with their tenants is welcomed, but the extent to which they will feel compelled to comply is unclear. Proposals for 'no quibble' payments where rooms are delivered late will also be beneficial to students, but these payments will only compensate the financial losses and inconvenience and cannot give them back the early weeks of university life. The right to be released from the contract where the building is not delivered is also welcomed, but it is only helpful where alternative accommodation is available. None of these improvements will give students back the carefree weeks they hoped to enjoy at the beginning of term to focus on making friends and finding their feet away from home. Unipol need to ensure that enhancements to the code are sufficient to deter PBSA providers from engaging in behaviours that will adversely affect students. The protocol on late delivery is welcomed in this regard, 
but if providers breach this protocol the damage will already be done by the time students are aware of the breach.

Studies show that students in the PRS are unlikely to complain directly to their landlord and where they do are even less likely to take steps beyond an initial complaint. Instead, they may well merely let the tenancy run out and chalk it up to experience, moving to a different house after the tenancy expires. In the absence of an ombudsman scheme the main method of redress for tenants in the PRS is bringing a claim in the county court. It is clear that litigation is not the best method of redress for consumer issues and litigation is even more challenging for issues of repair which have more complex evidential requirements than most consumer issues. The extent to which students would engage with an ombudsman scheme is unclear particularly as the short duration of any relationship with a landlord makes ex post solutions unlikely to succeed.

The conclusion of this analysis seems fairly bleak with neither regulation of contract terms nor current or proposed redress schemes providing a complete solution for the problems faced by student tenants. It would seem that a consumer led approach does not provide much of a solution for student tenants.

\section{(b) Proposals for reform}

Tenants are unique in terms of the nature of the product that they consume, a home, and the relationship they have with the supplier of that product. Neither adjustment of the contract to ensure transparency and remove unfair terms nor an ombudsman scheme for complaints provides an adequate solution.

What is clear is that prevention is better than cure. If we are to view students in the PRS as consumers we need to consider how we ensure that the product they are buying is fit for purpose in the first instance. Whilst the Homes (Fitness for Human Habitation) Act 2018 requires that a dwelling be fit at the grant of the tenancy a landlord will only have to act when formally notified of the failure of repair. 
If the common student problems of damp and vermin do not become apparent until mid-way through the first term it is understandable that students will see no point in taking matters beyond informal (if perhaps repeated) complaints. Furthermore, whether or not a property is in breach of the legislation requires a level of expertise. In addition to having to navigate a complex area of the law, students also need to determine whether the property technically in 'disrepair' which also requires specialist knowledge that tenants do not have.

In order to ensure that a rented property is 'fit for habitation' it needs a survey. This does not need to be the kind of survey undertaken by a prudent commercial tenant or purchaser but rather an inspection report to check that the property is free of the kinds of issues identified in the legislation. Landlords are already required to obtain gas safety certificates every year so such a recommendation is not unduly onerous. The risk of imposing further conditions upon landlords is clear, they either leave the market place or pass the costs on to the tenant in the form of increased rents. However, the cost of an annual inspection report could quite sensibly be a tax deductible expense. A further issue might be the costs of works necessary to bring an unfit home up to standard. There are a variety of ways that this could be done. A detailed discussion of the best approach is beyond the scope of this article but tax incentives or government grants are obvious potential solutions.

There are additional measures necessary that naturally flow from a requirement for properties to certified in the way proposed above. The scheme would have to be monitored and enforced. Here the both the local authority and universities have a role to play. Local authorities already have considerable statutory powers with regard to licencing, inspection and enforcement. Expanding the licencing requirements to require landlords to prove fitness prior to obtaining a licence could fit within this existing regime. Again, funding is likely to be an issue with many local authorities have insufficient housing or environmental health officers. Further research is needed to ascertain how best this provision could be funded. 
Universities can assist by creating their own accreditation schemes following the example of Manchester University. These schemes can go beyond the basic requirements of fitness provided for in the legislation and evidenced by certification. Such schemes can provide information to students about what to expect and their responsibilities as tenants as well as providing easy to access complaints system with the possibility of mediation. Universities can also follow the lead of Manchester University and award additional accreditations for 'international friendly' and 'disability compliant' properties and even give properties a quality rating. The advantage in universities taking a front seat in this process is that students are likely to feel more comfortable in accessing services within the bounds of their institution. University staff with pastoral roles would also find it easier to make a referral to a university service rather than suggesting that students contact the local authority environmental health officer or Citizens Advice. A well-funded university housing service can also work to collaborate with representatives of the local community and local housing officers to promote the interests of both students and the local community. Many universities already provide housing services and advice beyond promotion and provision of their own halls. However, they would be better able to assist students if local authorities could do the heavy lifting of enforcing housing standards. How universities fund this provision would need further detailed consideration, but students provide an income and universities might consider better housing assistance to be a useful addition to their welfare budget.

Working with both local landlords and the local authority in this way universities could be integral in improving student experience of accommodation. The costs of licencing and/ or accreditation schemes are considered to be a significant barrier. However, renting to students often yields higher rents than ranting to families and it could therefore be argued that student landlords are able to bear this cost. Requiring local authorities to play a greater role also has cost implications, but it is worth remembering the very considerable positive impact that students have on local economies. Universities may also be reluctant to be the first port of call for student housing complaints, but as the first port of call for student welfare issues it could be beneficial for universities to take a more 
proactive approach to ensuring students are well housed. Further research on the impact of student housing on welfare and success would be welcomed in informing the debate as to who should pay for the cost of better enforcement of students' housing rights.

Local authorities and universities also have a role to play in improving outcomes for students in the PBSA sector. Local authorities need the PBSA sector and are able to use PBSA to account for the housing needs of students as required by local plans Local planning authorities have wide ranging powers in determining planning applications including refusal of an application or granting an application with conditions. ${ }^{122}$ The requirement for private providers of accommodation in the PBSA to enter into a contractual relationship with a university could be imposed as a planning condition and this might assist the flow of information between providers, universities and students enabling better assistance to be provided to students when buildings are delayed or other problems occur. Universities could also take a more proactive approach in encouraging all providers of PBSA to become part of their accreditation schemes.

122 Town and Country Planning Act 1990 s 70(1)(a). 